\title{
LA PARTICIPACIÓN COMO UN ACTO EDUCADOR Y CONSTRUCTOR DE LA CIUDAD EDUCADORA. ${ }^{1}$
}

\author{
THE PARTICIPATION AS AN EDUCATING AND A \\ CONSTRUCTIVE ACT OF THE EDUCATING CITY
}

Jahir Rodríguez Rodríguez

Palabras Clave: Educación, democracia, participación, acción, Ciudad Educadora, emancipación, pedagogía, educar, pedagogía de la ciudad, escuela.

Key words: Education, democracy, participation, action, Educating City, emancipation, pedagogy, educate, pedagogy in the city, school.

La ciudad es la gente. Sófocles

\section{ABSTRACT}

The construction of a pedagogical project of the Educating City upon the frame of globalization processes of democracy, constitutes a great challenge for citizen participation, and consequently, a dare to the education actions, understanding by an educating act as a political and ethical act that opens doors to knowledge and the construction of a new and active citizenship committed to the urban project in its own city.

The pedagogical act of learning-teaching process of the city constitutes an interdisciplinary process where the knowing of the knowledge object and the didactic principles that give direction the scientific, critical and reflexive appropriation of the city converge in their many complex processes such as historical, socio-economic, political, cultural, ethical among other aspects.
1 Ponencia presentada el Simposio, CIUTAT. EDU: NOUS REPTES, NOUS C O M P R O M I S O S . Repensar la ciudad desde la educación, Barcelona, octubre 9, 10 y 11 de 2006.

2 Magíster en Ciencias Políticas; Magíster en Educación; Planificador urbano. Educador popular. Director de la Maestría en Desarrollo Regional y Planificación del Territorio : Coordinador del Grupo de Investigación en Desarrollo Regional, Universidad Autónoma de Manizales. Colombia. jahirr@telesat.com.co
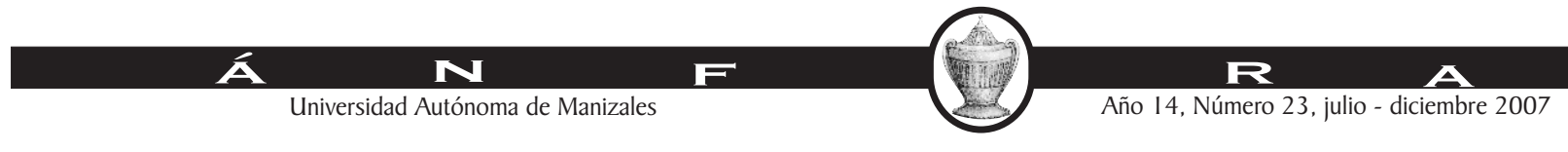
It is essential to feed participation along with the formation process of human beings. We need to feed it since the childhood. That participation must be learned and fed, otherwise it can get lost. Once it is lost, depression takes place and leads to a state where democratic participation is impossible.

However, the participation has another very important connotation for cities development which becomes in an irreplaceable technical instrument when dealing with method conceptions or forms of planning whose expressions are different kinds of plans that are available for city planning experts nowadays. Currently, a planning process lacking participation is considered hardly sustainable and unfeasible.

To sum up, the social existence of human beings can only be perpetuating through the continuous perfecting of their social conscience. Education plays a significant role in the previous idea because its efficiency is directly proportional to the achievement of reflexive subjects committed with their social and cultural surroundings. When transmitting the fundamental features of culture, all educative projects can also be called political acts.

\section{RESUMEN.}

La construcción como proyecto pedagógico de la Ciudad Educadora en el marco de los procesos de la globalización de la democracia se constituye en un gran reto para la participación ciudadana y a su turno, en un desafío para las acciones de la educación, entendido el acto de educar, como un acto político y ético que abre el camino al conocimiento y a la construcción de una nueva ciudadanía activa y comprometida con el proyecto urbano de su ciudad.

El acto pedagógico de la enseñanza-aprendizaje de la ciudad constituye un proceso interdisciplinario donde confluye el conocimiento del objeto de saber y los fundamentos didácticos que orientan la apropiación científica, critica y reflexiva de la urbe, en sus múltiples y complejos procesos: históricos, socio-económicos, políticos, culturales, éticos, entre otros aspectos.

Es necesario cultivar la participación con la formación del ser. Tenemos que cultivarla desde la infancia, desde los niños pequeños. Eso se 
aprende y se cultiva, y si no se cultiva se pierde, y cuando se pierde se entra en la depresión, y en ese estado no hay posibilidad de convivencia democrática.

Sin embargo, la participación posee también otra connotación muy importante para el desarrollo de las ciudades, cual es la de constituirse en un instrumento técnico insustituible a la hora de concebir métodos o formas de planificación, cuyas expresiones son los planes de variado tipo que ahora están a disposición de los urbanistas. Hoy día un proceso de planificación carente de participación es algo difícilmente sostenible y de imposible práctica.

En definitiva, La existencia social del hombre, sólo puede conservarse a través del perfeccionamiento continuo de su conciencia social, en ello la educación juega un papel fundamental, de la eficacia con que se desarrolle, depende el logro de un sujeto reflexivo, comprometido con su entorno social y cultural. Al transmitir los rasgos fundamentales de la cultura, todo proyecto educativo, es también un acto político.

La estructura del artículo. El documento se desarrolla en tres capítulos los cuales centran su reflexión en las relaciones que se establecen entre la escuela y la ciudad, en donde la participación, el diálogo y la democracia se constituyen en los elementos que articulan la nueva ciudadanía.

En palabras iniciales, se presenta un debate entorno al concepto de Educación pensado y reflexionado desde la filosofa Alemana, Hannah Arendt; en el primer capítulo, la ciudad como espacio educador, se plantean unos argumentos a favor de la tesis de que la ciudad es esencialmente un espacio donde se educa, construye la ciudadanía, y es la ciudad la que tiene que jugar un papel en el respeto y la construcción de las identidades múltiples y sus valores que reclama la época contemporánea; en el segundo capítulo, el currículum de la ciudad, recupera la idea que existe a lo largo de los espacios construidos socialmente por el hombre como ser histórico, otra educación, que se vive y disfruta en cada rincón de la ciudad, como un currículum oculto que se abre a la vida de la ciudad en cada momento que se busca su quehacer pedagógico; en el tercer capítulo, la participación como proceso educativo, se reflexiona sobre el papel político de la 
participación y ésta como contribuye a una democracia más abierta, donde la participación debe estar destinada no sólo a consolidar la democracia como régimen político, sino a potenciar y fortalecer el desarrollo de la democracia como un estilo de vida que favorece nuestra convivencia; y finalmente se deja consignado un sueño de escuela y un propósito de Ciudad Educadora, a manera de reflexión.

\section{PALABRAS INICIALES.}

\section{El sentido de la política es la libertad.} Hannah Arendt

Cómo entender la educación. Con Hannah Arendt, en cuyo pensamiento se inspira esta reflexión, podemos entender la educación como acción. La acción es la actividad humana fundamental por la que aparecemos en un espacio común o público como seres únicos e irrepetibles. Arendt entiende esta aparición como autorrevelación, que no sólo es revelación de uno mismo a uno mismo, sino también, y sobre todo, una revelación de uno mismo ante los demás. Por eso, la educación guarda similitudes con la esfera de lo público, o, vale decir, con la política, con los espacios de la ciudad. Esto lleva a plantear la convicción de que la educación, como acción educativa, tiende a reforzar la esfera pública desde su ámbito específico.

En La Condición Humana, libro que para muchos es la principal obra teórica de Arendt, la acción, la actividad política, aparece descrita, por encima de la labor y el trabajo, como aquella actividad a través de la cual el individuo se realiza como propiamente humano: "Mediante la acción y el discurso, los hombres muestran quiénes son, revelan activamente su única y personal identidad y hacen su aparición en el mundo humano. ${ }^{\prime 3}$

Arendt distingue claramente la acción -que incluye la palabra- de lo que ella llama comportamiento, y en general de las otras actividades - labor, trabajo -, en las cuales el individuo tiene determinadas conductas y funciones con respecto al mundo, a los demás o a la naturaleza, pero no se revela como tal. Esto sólo sucede como hemos dicho en la acción, que es por esencia política, o sea, fundada en la pluralidad y garantizada en su permanencia por la organización de la polis, es decir, "la organización de la gente tal como surge de actuar y hablar juntos". ${ }^{4}$ Expresándose en una forma que valoriza explícitamente el carácter agonista de la acción,
3 ARENDT, Hannah. La Condición Humana. Paidós. Barcelona. 1993. pág. 203.

4 Ibid, pág. 221.

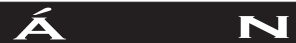

Universidad Autónoma de Manizales 
Arendt dice que: "la cualidad reveladora del discurso y de la acción pasa a primer plano cuando las personas están con otras; la acción política necesita para su plena aparición la brillantez de la gloria, sólo posible en la esfera pública." ${ }^{5}$

Recordemos que para Arendt la acción, unida y acompañada siempre por la palabra -opinión-, es la más alta cualidad humana. La acción es para ella la capacidad de libertad por excelencia, la capacidad de iniciar nuevos acontecimientos, situaciones inéditas en medio de la pluralidad, condición sine-qua-non de la vida política -y no meramente biológicadel ser humano, y a partir de un hábitat constituido, no sólo por la naturaleza, sino particularmente por el mundo del artificio humano, la mundanidad.

Si la acción y la palabra tienen su asiento básicamente en la pluralidad y en la mundanidad, además del mundo natural al que pertenecemos -lo dado-, es fácil entender que quien está privado de mundo -hogar, tierra natal, pertenencias, referencias culturales, etc- y privado de formar parte de una pluralidad que lo reconozca como uno de los suyos -sin patria, sin ciudadanía- es decir sin status político, queda también privado de aquello que le permite a los demás reconocerle como humano, pues sólo conserva aquello que la naturaleza le ha dado: su cuerpo desnudo y sus funciones biológicas. Para ser reconocido como ser verdaderamente humano es pues preciso, como dice Arendt, tener un status político, ser ciudadano, tener un "lugar" en el mundo a partir del cual hablar y actuar.

Emancipación y Ciudad Educadora. El concepto está asociado a la acción, por lo tanto un acto de emancipación que cuestione los valores y la estructura de una sociedad determinada y que actúe para corregirlos o transformarlos, es un movimiento que navega, irremediablemente, por aguas de lo político y de lo ético. La doble dimensión política - ética de la acción también se fundamenta en los objetivos y en la intencionalidad que se tiene. A grandes rasgos, y no sin miedo de incurrir en una simplificación, podemos decir que la dimensión política de la estrategia de Ciudad Educadora, sus metas, sus actos y acciones han sido y son, la búsqueda de la igualdad, la equidad, la emancipación, la libertad o la autonomía de los ciudadanos y con ello buscar la autonomía individual y colectiva de los actores con los cuales interactúa.
5 Ibid, pág. 204

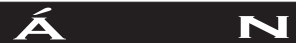

Universidad Autónoma de Manizales 
Aproximarse a cualquiera de estos conceptos, - política y ética pensarlos o encaminar esfuerzos a su ejecución, pasa por cuestionar y enfrentarse a la estructura cultural y política de la sociedad en la que actuamos y a la cual le damos la definición de CONTEXTO; por lo tanto, nuestra acción se debe reflejar en él.

Ambos conceptos deben ser vistos desde una concepción amplia y flexible de los términos. En este sentido, lo "político" no se restringe al ámbito de lo público y a las decisiones de partidos políticos, actores políticos, instituciones o gobiernos. La política impregna todos los aspectos de nuestras vidas, se encuadra en el marco de la acción, y la institución educativa es por naturaleza en un espacio donde se hace y ejercita la política día a día, en cada espacio, en cada momento, en sus currículos, en la cátedra que se fundamenta en el conocimiento, en la práctica de las ideas, en sus actos de autonomía y libertad. ${ }^{6}$

Kate Millet lo expuso brillantemente al decir que "lo personal es político", máxime ahora que las fronteras de lo privado y público se diluyen, se mezclan y se alimentan, por lo que pensar y actuar en el espacio personal tiene implicaciones políticas a todos los niveles. "Actuar" puede ser entendido en este punto bajo el prisma filosófico con el que lo proyecta Arendt: ese momento en el que el ser humano desarrolla la actividad que le diferencia del resto de los animales, la capacidad de ser libre. Pero la libertad de Hannah Arendt no es mera capacidad de elección, "sino capacidad para trascender lo dado y empezar algo nuevo, y el hombre sólo transciende enteramente la naturaleza cuando actúa." 7

Desde el punto de vista de Hannah Arendt, ésta habla del "hombre" y del "ser humano" para referirse tanto a hombres y mujeres. Haciendo propio su pensamiento, rescataré aquí la idea de que para ser libre no sólo es necesario el pensamiento: "sólo pensar no nos hace libres, porque la libertad se muestra en la acción, en la intervención en el mundo para hacer aparecer algo que previamente no existía. Pensar es un ejercicio en soledad $y$, en cambio, ser libre es actuar, lo que requiere la participación de otros seres humanos". ${ }^{8}$

En este orden de ideas, la pluralidad humana, básica condición tanto de la acción como del discurso, tiene el doble carácter de igualdad y distinción. Si los hombres no fueran iguales, no podrían entenderse ni
6 "Autonomía" y

"libertad" son concebidas en este texto como facultades propiamente humanas.

7 ARENDT, Hannah, Op. Cit. pág. 200.

8 LARRAURI, Maite, La Li bertad, s e gún Han a h Arendt. Filosofía para profanos No. 3, Valencia, Tándem Ediciones, 2001, pág. 24

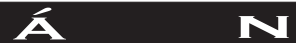

Universidad Autónoma de Manizales
F

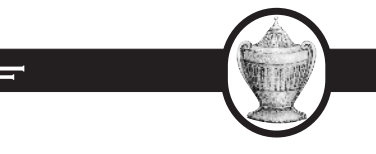

Año I4, Número 23, julio - diciembre 2007 
planear y prever para el futuro las necesidades de los que llegarán después. Si los hombres no fueran distintos, es decir, cada ser humano diferenciado de cualquier otro que exista, haya existido o existirá, no necesitarían el discurso ni la acción para entenderse. ${ }^{9}$

\section{La sociedad del aprendizaje. ${ }^{10}$}

Hoy la construcción social y política como proyecto pedagógico de la Ciudad Educadora, nos obliga a asumir el desafío de educar en y para la libertad, que ha de ser, educar en la responsabilidad y el compromiso, y el proceso educativo ha de desarrollar las virtudes y capacidades que el ser humano requiere para ser libre. Para ello, la formación, lejos de ser neutral, ha de ser plural, poniendo al alcance de los educandos todas las opciones, alternativas y posibilidades que le permitan ejercer su capacidad de elegir, responsablemente, lo que mejor convenga a sus circunstancias personales, históricas y sociales. Asimismo, ha de propiciar el compromiso individual en proyectos comunes, para que en la práctica el educando se acostumbre a que una elección no solamente es un juicio, sino que implica acción: el individuo ha de actuar en forma correspondiente a sus elecciones.

La educación no es mera instrucción escolar. La incluye, pero va más allá. En la escuela se establecen relaciones pedagógicas y sociales específicas, que van dejando huellas en las personas que de ellas participan.

La educación es el terreno donde el poder y la política se expresan de manera fundamental, donde la producción de significado, de deseo, lenguaje y valores está comprometida y responde a las creencias más profundas acerca de lo que significa ser humano, soñar y dar nombre y luchar por un futuro y una forma de vida social especial. La educación se convierte en una forma de acción que va asociada a los lenguajes de crítica y posibilidad. Representa, finalmente, la necesidad de una entrega apasionada por parte de los educadores para hacer que lo político sea más pedagógico, es decir, para convertir la reflexión y la acción críticas en partes fundamentales de un proyecto social que no sólo se oponga a las formas de opresión sino que, a la vez, desarrolle una fe profunda y duradera en el esfuerzo por humanizar la vida misma. ${ }^{11}$
9 Cfr. ARENDT. Op.cit. pág. 67

10 MARINA TORRES, José A $n$ t $O \mathrm{n}$ i o. L a c o n s p i r a c i ó n educativa. Extraído de un a conferencia organizada por el Consejo Escolar de Navarra. Barcelona, 2006, pág. 60

11 GIROUX, Henry. Los profesores como intelectuales. Paidós. Barcelona, 1990 pág. 161
A N

Universidad Autónoma de Manizales 
En la medida en que la educación cumple con funciones para la construcción de la sociedad, no es una novedad la relación entre ella y la forma de organización social. La relación entre educación y democracia, entonces, puede verse desde dos muy distintas perspectivas: la educación democrática y la educación para la democracia.

La educación democrática, entendida como la práctica de la democracia en el interior del proceso enseñanza-aprendizaje, la dejaremos para análisis ulteriores. Hay quienes proponen que la escuela y la universidad, e incluso la familia, han de ser instituciones democráticas. Nosotros consideramos que las iniciativas por "democratizar" la escuela y la enseñanza confunden sus propuestas activas de mayor libertad de acción y opinión, de participación de los alumnos, de trabajo colectivo, de pluralidad y de libertad de cátedra, con lo que significa y representa la democracia.

La educación para la democracia es una tarea de la educación cívica que pretende, entre otras cosas, la formación de ciudadanos que ejercen con libertad e igualdad sus obligaciones políticas y civiles para la construcción de una sociedad pluralmente representada y para su participación responsable y comprometida en la vida pública.

Por esto la educación y en particular, una educación que relaciona la escuela y la ciudad son partes imprescindibles de cualquier formación humana. No se puede formar solamente a las personas desde el punto de vista laboral; formarles para que sepan apretar botones o para que cumplan funciones más o menos gestoras, sin haberles formado la capacidad de convivencia y ciudadanía, que no surge naturalmente de las personas. Los demócratas no surgen de las piedras naturalmente, como las flores silvestres; hay que cultivarlos, regarlos. Los griegos tenían claro que la paídeia era una parte absolutamente Imprescindible de la democracia; que precisamente, la democracia es, ante todo, una máquina de crear demócratas, si no está perdida. Para crear esos demócratas hay que formarlos, dar unos principios elementales, hay que aprender a discutir y discutir mientras se enseñan los principios.

Como bien apunta Savater: "Lo que hace humana a la vida es el transcurrir en compañía de humanos, hablando con ellos, pactando y mintiendo, siendo respetado o traicionado, amado, haciendo proyectos 
y recordando el pasado, desafiándose, organizando juntos las cosas comunes, jugando, intercambiando símbolos". ${ }^{12}$

La transformación del sentido de la palabra "ciudad", que heredamos de la "civitas" romana y de su precedente griego "polis" que todavía vive en nuestras palabras "política", "policía", etc., indica que la revolución de los conceptos no es simplemente una evolución o transformación de su contenido. Tanto "civitas" como "ciudad" admiten las dos interpretaciones: piedras o actividad humana. Pero el aspecto del concepto ha cambiado. Al decir civitas pensaban los romanos en primer lugar en la actividad humana y sólo en segundo lugar en la estructura física, mientras que para nosotros la palabra "ciudad" despierta inmediatamente la imagen de las calles y sólo en acepción secundaria nos permite pensar en los seres humanos. Traducir por lo tanto "civitas" como "ciudad" sin más, no es incorrecto, pero conlleva cierta confusión. Nuestra palabra "ciudad" no designa ya en primer lugar la vida ciudadana, sino el escenario en el que esa vida ciudadana se desarrolla.

Por estas razones creemos que desde la Ciudad Educadora, debemos hablar de la sociedad del aprendizaje. Como nos lo ilustra nuestro apreciado profesor Marina, cuando advierte: "... tengan en cuenta que hemos entrado en la sociedad del aprendizaje, que vamos a tener que estar continuamente aprendiendo, y que cada vez se están transfiriendo más responsabilidades al sistema educativo. Pronto tendremos que hacernos cargo de alumnos recién nacidos. No somos los educadores los que nos empeñamos en arramblar más competencias. Es la sociedad la que nos lo exige. ${ }^{13}$

\section{LA CIUDAD COMO ESPACIO EDUCADOR.}

La ciudad es un marco y un agente educador que, ante la tendencia a la concentración del poder, practica la opinión pública y la libertad; ante la tendencia al gregarismo, expresa el pluralismo; ante la tendencia a distribuir desigualmente las posibilidades, defiende la ciudadanía; ante la tendencia al individualismo, se esfuerza por practicar la individualidad solidaria... permite formar personas sensibles tanto a sus deberes como a sus derechos ${ }^{14}$
12 SAVATER, Fernando, La tarea del héroe. Editorial Destino, México, 1994, pág. 125.

13 MARINA TORRES, Op. Cit. Pág. 92

14 MOLAS BATLLORI, Isidre. La ciudad y la ciudadanía democrática. Una perspectiva política. En: La Ciudad Educadora. Barcelona. 1990. Pág. 48.

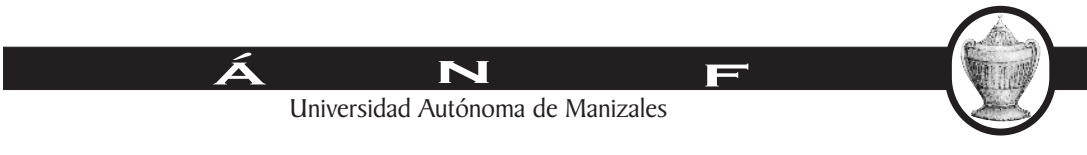


Sobre el escenario de la historia de la humanidad y sobre el teatro de la civilización occidental se alzan los bastiones de la ciudad, sobre ellos el ideal pedagógico cobra vital importancia en el proceso de construcción de identidad y de construcción de ciudad. Se destaca que la construcción de las ciudades debe llenarse de expresión y contenido, de tiempo y espacio, de pensamiento y de acción, de geografía e historia, de realidad y proyecto.

Mario Gennari ha subrayado que la antropología pedagógica de la ciudad es la expresión que conviene a cualquier intento de abordar adecuadamente una antropología urbana. La idea está también presente en la filosofía de Platón y Aristóteles, en la poesía de Goethe y Flaubert, en la literatura de Dostoyevski y Thomas Mann o en la pedagogía de Agustín de Hipona y Rousseau. ${ }^{15}$

La pedagogía de la ciudad nace al mismo tiempo que el conocimiento y la conciencia del producto humano en que consiste la ciudad; ésta en definitiva, cuenta mediante la historia de su diseño urbano, su pedagogía, la misma historia de los hombres que han habitado en ella.

Cada ciudad traduce una imagen simbólica que el tiempo calcifica en la conciencia de los hombres y en la síntesis cultural de la civilización, la ciudad, al igual que el hombre, se forma a través de la mediación entre idealidad con realidad.

El ideal pedagógico de la ciudad sondea el significado de la educación del espacio urbano y ejercita una formación humanística centrada en los valores éticos y estéticos que le proporcionan al hombre los valores de su actuación y el reconocimiento como ser social. Así los ideales de la pedagogía son partes constitutiva del humanismo y la construcción de la ciudad. Al primero le sucede el urbanismo y al segundo el hombre.

La pedagogía relaciona y desarticula la dis - conformidad entre la ciencia y la cultura, la filosofía y la historia; no anula la especificidad de cada una de ellas, sino que al mediarlas posibilita su identidad y diferencia. $Y$ en un sistema de hegemonía cultural determinado, la pedagogía es el hiato del bloque histórico "la soldadura" de la cultura y de la filosofía.

En la llamada "pedagogía creativa", ${ }^{16}$ para Gramsci la relación pedagógica no es la transmisión del conocimiento ni siquiera de la
15 Cfr. GENNARI, Mario. Semántica de la ciudad y educación. Pedagogía de la ciudad. Herder. Barcelona. 1995. pág, 56

16 Cfr. GANTIVA SILVA, Jorge. Un ensayo sobre Gramsci. Editorial del Magisterio. Bogotá. 1998. pág. 21.

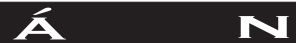

Universidad Autónoma de Manizales
F

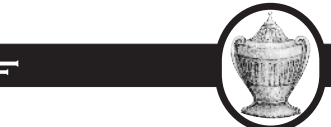


cultura, sino ante todo, la articulación de la historicidad y de la conciencia de dicha historicidad por el individuo como por el pueblonación.

Entiende Gramsci por creativo, el sentido relativo al pensamiento que modifica el modo de sentir del mayor número y, por lo mismo, la propia realidad, que no puede ser pensada sin este mayor número. Creativo, también la reconstrucción del concepto de creatividad abarca y compromete los términos de participación-comunidad y socialización.

Esto es, sitúa la Escuela, el estudiantado, los individuos y, en general, a la sociedad civil en el mundo de la vida, en la historia como portadora y creadora de alternativas sociales y culturales. Se trata de desarrollar la personalidad histórica de la escuela y de la cultura y, para ello, la pedagogía desempeña un papel de primer orden.

En esta dialéctica saber-comprender-sentir y sentir-comprender-saber, los intelectuales, los maestros producen una relación de intercambio de elementos individuales entre gobernantes y gobernados, entre dirigentes y dirigidos. O sea que se realiza la vida de conjunto, exclusivamente, en la fuerza social; se crea el "bloque histórico" -según lo expresa el pensador italiano- en el proceso de la construcción del ser.

La pedagogía no reemplaza la política, su misión es precisamente romper sin violencia con las ataduras, desarrollar la innovación social desde la formación de nuevos ciudadanos, abrir esperanzas de cambio hacia un mundo mejor sobre la base de la comprensión, la solidaridad y el consenso voluntario de las personas.

Este es el fundamento de la verdadera democracia, la comunicación libre de dominación y el mutuo reconocimiento entre los ciudadanos y las comunidades. En palabras de Misgeld: La educación es un proceso por medio del cual enseñamos los unos a los otros el respeto por las capacidades humanas de tolerar, de responder con honestidad, dignidad y coraje a situaciones exigentes. No creo que exista un programa o una técnica para lograr esto que no sea la comunicación constante y la presencia de cada uno de nosotros en el otro.

La educación es pues la base, el órgano genital de la democracia y, a la vez, la democracia es educadora. Así aprenderá el niño educado en la

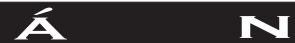

Universidad Autónoma de Manizales 
democracia a no agredir a su congénere, a reorientar su agresividad hacia el amor, hacia la defensa de la vida y evitar que se convierta en destrucción y muerte: "Hay que enseñarle a los niños a dejar el combate sin perder la combatividad. A ser fuerte pero sin perder la ternura ni la compasión por el otro... el otro por ser diferente puede ser complemento, o quizás mi opositor pero nunca mi enemigo. Ello significa aprender a valorar la vida del otro como mi propia vida, valorar la diferencia." ${ }^{17}$

El nuevo ciudadano educado y formado en el marco de un proyecto de Ciudad Educadora debe aprender a pensar pensando, aprender a hablar hablando por cuenta propia, aprender a respetar reconociendo su propia dignidad, aprender a escuchar en la reciprocidad de la palabra. El derecho a hablar no es un fin en sí mismo, se conquista, se legitima, al enunciarle al otro algo diferente.

La Ciudad Educadora no se construye de una vez para siempre. Está en constante avance. Es a la vez realidad presente y utopía futura. El concepto de ciudad sana supone un reto para las ciudades con dos cuestiones simples: qué es una ciudad sana y cómo podemos conseguirla. El intento de responder a la primera nos lleva al reino de las utopías; la respuesta a la segunda nos enfrenta de cara con la realidad.

El diálogo en la Ciudad Educadora. ${ }^{18}$ El diálogo en su más alta expresión puede ser considerado como una virtud cívica de carácter democrático desde una doble perspectiva: por un lado, porque evita el recurso de la coerción y la violencia y, por otro, porque abre la posibilidad de cambiar libremente de opinión sin que exista represalia alguna. El imperativo del diálogo democrático, en consecuencia, es el de no usar la violencia en contra del disidente, es decir, en contra de quien profesa ideas distintas.

El diálogo también da vida a las "reglas del juego" con las que se toman las decisiones colectivas en un régimen democrático, contribuyendo de manera decisiva a su buen funcionamiento y expansión. La importancia de lo anterior es evidente: en una democracia, las decisiones se deben adoptar bajo la "regla de la mayoría", pero cuidando siempre de no vulnerar los derechos de las minorías.

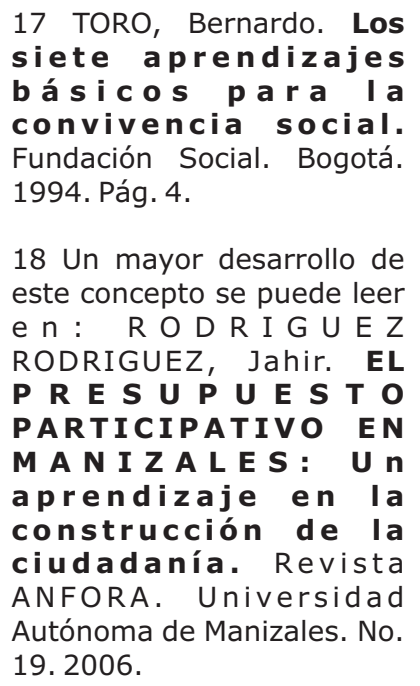

18 Un mayor desarrollo de este concepto se puede leer e $n$ : RODRIG UEZ RODRIGUEZ, Jahir. EL P R E S U P U E S T O PARTICIPATIVO EN M A N I Z A LE S: U n aprendizaje en la construcción de la ciudadanía. Revista ANFORA. Universidad Autónoma de Manizales. No. 19. 2006.

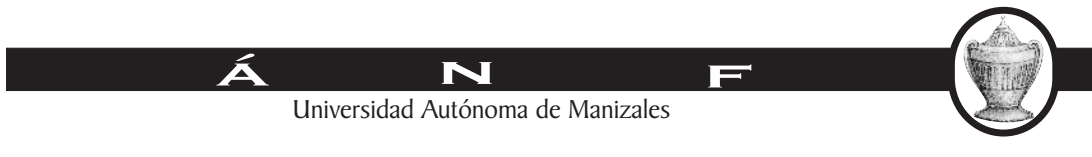


El diálogo se relaciona inevitablemente con la existencia del otro, de la contraparte. Dicho de otra manera, la condición necesaria del diálogo es la existencia, por lo menos, de dos puntos de vista diferentes que, sin embargo, pueden relacionarse entre sí al establecer la posibilidad de construir un acuerdo basado en supuestos comunes. Por lo tanto, y de acuerdo con algunos estudiosos, "la actividad política se sitúa en un espacio público en donde los ciudadanos pueden encontrarse, intercambiar opiniones y confrontar sus diferentes puntos de vista, buscando una solución consensual a sus problemas colectivos". ${ }^{19}$ Desde esta óptica, la política representa el espacio de la presencia común, en donde pueden surgir, articularse y ser analizadas cuestiones de interés público desde diferentes perspectivas.

Entre las prácticas que se contraponen al diálogo, y por ende a la democracia, podemos considerar el monólogo y la indiferencia, entendidas ambas actitudes como la negación de uno de los actores y, en casos extremos, como una negación recíproca. No debemos olvidar que estos comportamientos se encuentran en la base de todas las intolerancias. Frente a ello, resalta el valor de una coexistencia pacífica de tipo cooperativo en la que prevalecen las garantías necesarias para que los ciudadanos expresen sus opiniones libremente, haciendo posible la adopción de acuerdos entre los diferentes actores orientados a fortalecer la pluralidad democrática.

De esta manera, el poder público obtiene beneficios de la existencia de una ciudadanía libre e igual en cuanto cuerpo colectivo. Para que "la política pueda realizarse no es suficiente tener un grupo de individuos que voten separada y anónimamente con base en opiniones privadas, sino que es necesario que estos individuos puedan encontrarse $y$ dialogar en público, en un espacio compartido en el que sus diferencias y sus puntos en común puedan emerger y convertirse en el objeto de un debate democrático." ${ }^{20}$ Así, el diálogo se constituye en fundamento de la democracia moderna y ello se refleja institucionalmente en la existencia de un equilibrio entre una mayoría en el poder y una serie de minorías que aspiran a convertirse en mayoría mediante los mecanismos previstos por la ley. Al permitir el respeto a las opiniones diferentes, el diálogo se revela como una práctica útil y necesaria para la convivencia democrática que se traduce en la posibilidad concreta de encontrar puntos de acuerdo que permitan la coexistencia cooperativa del consenso y del disenso.

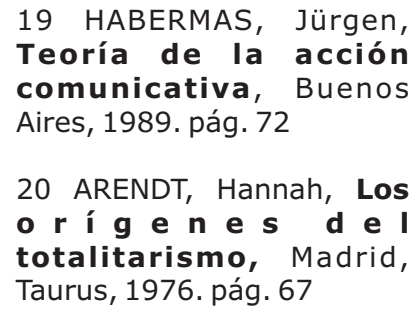

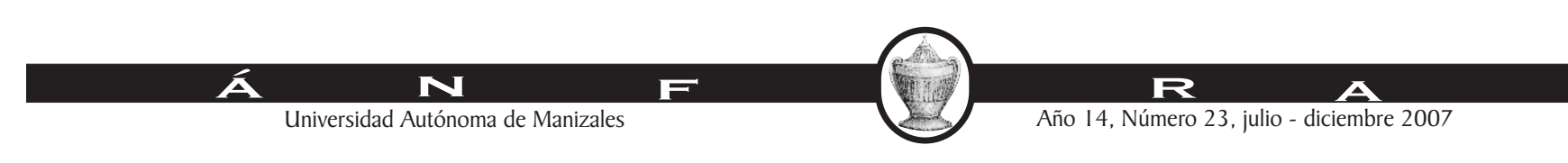


Debemos señalar que la coexistencia entre estos dos procesos supone el diálogo democrático a condición de que el consenso no sea total ni el disenso tenga un carácter extremo e irreductible. Por el contrario, en una democracia el diálogo contribuye a equilibrar las diferentes posiciones y a evitar la ruptura de las reglas y de los procedimientos a través de los cuales se desarrolla la convivencia pacífica entre ciudadanos con iguales derechos y obligaciones.

Entre los sujetos de la democracia encargados de promover este "intercambio" se encuentran, además de los individuos en cuanto ciudadanos, toda una serie de organizaciones de carácter político, social, cultural o religioso, como son los partidos, los sindicatos y los grupos de presión, que además de representar diferentes expresiones individuales y colectivas tratan de promover, legítimamente, sus propios puntos de vista.

La democracia fundamenta su existencia en una revalorización de la política, entendida principalmente como un medio para el establecimiento de pactos y acuerdos. Según la filósofa alemana Hannah Arendt, la política representa la experiencia de compartir un "mundo común" por parte de una diversidad de sujetos. En este sentido, las posibilidades del diálogo se encuentran determinadas por la capacidad de los distintos actores para enfrentar situaciones conflictivas mediante la negociación.

En esta perspectiva, el ejercicio del diálogo, por más inmediato y reducido que sea su alcance, posee un carácter constitutivo, ya que al rendir sus frutos en forma de acuerdos e intercambios refuerza dicha coexistencia pacífica. El diálogo debe concebirse, entonces, como una ampliación de los procesos de legitimación del funcionamiento del sistema político que responden a la dinámica de los distintos actores sociales. De esta forma, en una democracia el diálogo debe aparecer como parte integrante de un sistema de expectativas, de reconocimientos mutuos y de garantías recíprocas entre los actores sociales.

En definitiva, digamos que el diálogo entre iguales es una de las cualidades de la modernidad. 
2. EL CURRÍCULUM DE LA CIUDAD. La otra educación.

\section{En tanto educadora, la ciudad es también educanda.}

Paulo Freire

"En tanto educadora, la ciudad es también educanda". ${ }^{21}$ Ese es el "escenario" de la ciudad que educa en el cual las prácticas escolares posibilitan cualificar el entendimiento freireano tanto de la lectura de la palabra escrita como de la lectura del mundo. La ciudad que educa no se queda en lo inmediato, sino que apunta a una comprensión más analítica y reflexiva tanto de los problemas cotidianos como de los desafíos del mundo contemporáneo.

Hoy más que nunca la ciudad, grande o pequeña, dispone de incontables posibilidades educadoras. De una manera u otra, contiene en sí misma elementos importantes para una formación integral. La ciudad será educadora, cuando reconozca, ejercite y desarrolle, además de sus funciones tradicionales (económica, social, política, y de prestación de servicios) una función educadora. Cuando asuma la intencionalidad y responsabilidad cuyo objetivo sea la formación, promoción y desarrollo de todos sus habitantes. La ciudad será educadora si ofrece con generosidad todo su potencial, si se deja aprehender por todos sus habitantes y si se les enseña a hacerlo. ${ }^{22}$

Debido a la re-configuración cultural que ha sufrido la educación en la actualidad, se viene reconociendo una "generalización" de lo educativo en diferentes escenarios y procesos culturales, de modo que pensadores como Regis Debray señalan que la cultura contiene un "segmento pedagógico". ${ }^{23}$ Este señalamiento es bien importante, pues evidencia el declive de la hegemonía de la institución escolar en las sociedades contemporáneas, donde los significados de la Pedagogía se habían restringido a lo escolar, olvidándose sus significados complejos y polisémicos referidos a su sentido social y a prácticas sociales históricas muy diversas que le eran propias. Este fenómeno, que toma forma en la actualidad, recuerda que antes de existir la forma "escuela", las sociedades aprendían y se socializaban por medio de otras agencias culturales como la familia, las cofradías, los gremios de artesanos donde se transmitía el saber de los oficios a las nuevas generaciones, la comunidad local y la parroquial, entre otras.
21 FREIRE, Paulo. Política y educación. Santiago de Chile. pág. 23.

22 Cfr. Declaración del Primer Encuentro Internacional de Ciudades Educadoras. Barcelona. 1990

23 Cfr. DEBRAY, Regis. Transmitir. Ediciones Manantial, Argentina, 1997, pág. 93

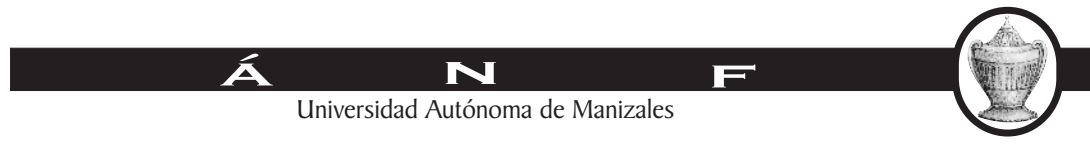


Igualmente, la educación se halla "descentrada" de sus viejos escenarios como la escuela, y sus prácticas, sujetos y narrativas han mutado y traspasado sus muros para extender su función formativa y socializadora a otros ambientes como la ciudad y las redes informáticas, a sujetos que no son necesariamente infantes sino también adultos, y mediando otras narrativas y saberes que escapan a la racionalidad ilustrada centrada en el discurso racionalista del maestro y en el libro, vehículo cultural por excelencia desde la Ilustración. De allí, que la Pedagogía haya dejado de ser tarea exclusiva de un Estado Docente y no se restrinja a funciones adaptativas/disciplinarias, lo cual lleva a interrogarse por su estatuto social, orientada a la construcción del tejido social, la valoración y resolución de conflictos en diversos ambientes y la animación de procesos culturales y comunitarios. Estos procesos han sido el resultado de las re-configuraciones culturales de la educación y del gran poder de los medios como agencias culturales, pues aunque no estaban pensadas para cumplir cometidos educativos, ejercen esta función con gran versatilidad plástica, y la aparición de nuevos procesos culturales donde los jóvenes, sus saberes y estéticas le imprimen su carácter a las sociedades urbanas.

Estas transformaciones han llevado a que especialistas de la Pedagogía Social como el español Antonio Petrus vean en la Pedagogía Social una "didáctica de las relaciones sociales", ${ }^{24}$ lo cual supone su rol socializador, dirigido a la adquisición de competencias, la participación social, la prevención de problemáticas y conflictos y a una mayor permeabilidad de los ámbitos institucionales educativos frente a sus entornos sociales de diverso orden. No obstante que la Pedagogía Social se ha identificado en sus desarrollos con enfoques dirigidos a la adaptación social, la socialización, la formación política del ciudadano y la prevención y el control social, estos no la agotan, especialmente cuando sus elaboraciones teóricas y de intervención están signadas por problemáticas culturales y sociales cambiantes y turbulentas que han configurado su carácter y sentido social, más allá del ámbito escolar institucional ${ }^{25}$

PEDAgogía URBANA. "Todo individuo debe tener la posibilidad de aprender durante toda su vida. La idea de educación permanente es la clave del arca de la ciudad educativa". ${ }^{26}$

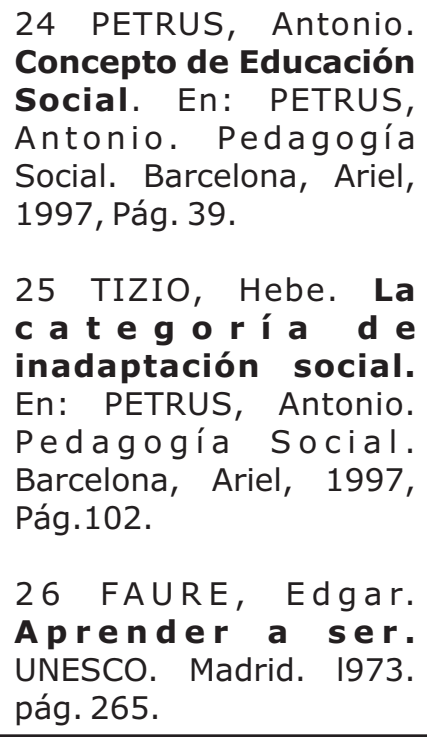


El principal núcleo de conocimiento u objeto de estudio lo constituye el binomio educación-ciudad; el que da lugar a una nueva disciplina o ciencia en el campo de la pedagogía. Así, la pedagogía urbana "daría cuenta razonada y coherente de la fenomenología propia que desarrolla la educación en el contexto urbano". ${ }^{27}$

No queda reducida -la pedagogía urbana- a la enseñanza ni tiene como sujeto exclusivo al maestro, sino que traduce el clima cultural de una época, de una formación social, de un bloque y abarca una diversidad de aspectos de la vida escolar y cultural que lo sella y re-orienta.

Los saberes y lenguajes de la ciudad. La ciudad, este espacio donde aparece el concepto de civilización -de civitas: ciudad-, es un sistema que se hace necesario leer para darle un carácter a lo político y al espacio público, que es donde el ciudadano es libre porque intercambia lo que hace. En este espacio, como sostiene Hannah Arendt, existe un ejercicio de la libertad y del trabajo libre, donde la propuesta dignifica el vivir y se opone radicalmente al trabajo servil, donde no hay proposición sino obediencia.

La ciudad, considerada al modo isidoriano y al aristotélico, supone una coordinación de saberes y actividades mediante las que los individuos hacen su aportación conjunta al bien común. Leemos en la Ética a Nicómaco lo siguiente: ...debemos determinar a grandes rasgos, al menos, cual es este bien y a cual de las ciencias o facultades pertenece. Parecería que ha de ser la suprema y directiva en grado sumo. Esta es, manifiestamente la política. En efecto, ella es la que regula qué ciencias son necesarias en las ciudades y cuáles ha de aprender cada uno y hasta qué extremo. Vemos además que las facultades más estimadas le están subordinadas, como la estrategia, la economía, la retórica. Y puesto que la política se sirve de las demás ciencias y prescribe además qué se debe hacer y qué se debe evitar, el fin de ella incluirá los fines de las demás ciencias, de modo que constituirá el bien del hombre.

La política es por consiguiente, para Aristóteles, el saber global de la ciudad, el conjunto de sus saberes y actividades. Decir "saberes y actividades" es aquí un tanto redundante.
27 COLOM CAÑELLAS, Antonio J. La Pedagogía Urbana, Marco Conceptual de la Ciudad Educadora. En: La Ciudad Educadora. Barcelona, 1990 . pág.119.

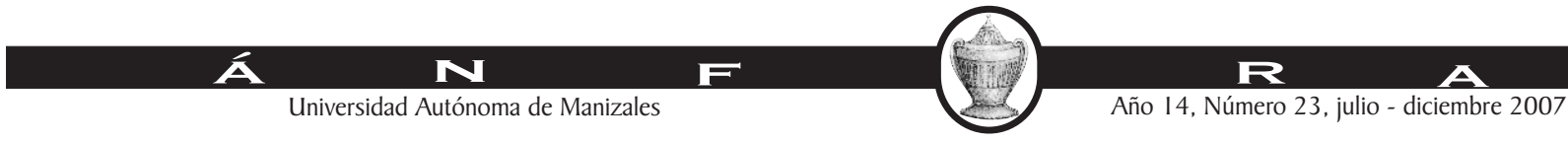


Es tarea fundamental de la ciudadanía el administrar y fomentar el desarrollo de sus saberes. Por eso, la formación humana, que los griegos llamaban paídeia, es la base de la vida de la ciudad democrática.

La formación humana no se basta con instituciones que dirijan el quehacer humano imponiendo el qué del hacer humano. La formación ciudadana exige instituciones que fomenten el cómo de actividades mediante las cuales los ciudadanos se hagan capaces de encontrar sus propios qués y de ir enseñándose unos a otros nuevos cómos en un ambiente de creatividad y concordia. Enseñar es mostrar cómo, no imponer qué.

La ciudad se forma de la articulación de dos tipos de discursos: un discurso del hacer que concierne a cada uno, de la tarea propia de cada individuo y cada empresa o institución, y un discurso del obrar que es un discurso ético que integra esos saberes y haceres particulares en un 'sentido común' que es el bien común de la ciudad.

Y desde el punto de vista de los lenguajes el escritor Cruz Kronfly, indica, "Una ciudad es, entonces, un denso tejido de evocaciones y recuerdos alrededor de sitios y lugares, olores y sonidos imborrables, murmullos de árboles y calles. A todo lo cual se llega luego de un agudo proceso de depuración y de olvido que solo deja en pie aquello que la subjetividad selecciona, en razón de oscuros criterios que la conciencia ignora. Pero, sobre todo, la ciudad se erige también como un sistema de usos que el sujeto interioriza, modos de utilización de vías y lugares, sombras, sitios de paso, recorridos y rutas y travesías, claves urbanas cuyo "saber" descifrar y utilizar resulta sustancial al adulto, en su adultez". ${ }^{28}$ Se ve pues que la ciudad es una realidad física donde se encuentran distintos intereses, pero es también una representación que tienen sus pobladores de acuerdo a su vivencia en la misma.

Esta concepción parte de reconocer que la educación no solamente ocurre en la escuela o en la familia, sino que ésta tiene ocurrencia en la ciudad y por los medios de comunicación masivos.

En el presente, la crisis de la escuela se acrecienta y aumenta la sensación de desvalorización social y la soledad de profesores y profesoras. La educación no busca sólo la acumulación de
28 CRUZ KRONFLY, Fernando. La ciudad como representación. En: Revista Politeía No. 17. Bogotá. pág. 43
A N Universidad Autónoma de Manizales 
conocimientos o ser competentes para el trabajo, sino que se busca que los individuos aprendan a ser y aprendan a decidir, como lo establece la UNESCO desde 1996. Es decir, la conformación de ciudadanías democráticas. Con lo cual debemos entender, "la formación de una ciudadanía creativa, capaz de transformar la información en conocimientos, que desde la diferencia afirme el respeto y la valoración del "prójimo", para proyectar juntos un futuro común de convivencia, activa y participativa, en la vida democrática, como lugar privilegiado para consensuar objetivos que compaginen los legítimos intereses individuales con los colectivos." ${ }^{29}$

Se debe buscar que la escuela siga cumpliendo la importantísima tarea que la ha asignado la sociedad, para lo cual debe transformarse, en una primera dimensión que todo el sistema educativo se involucre con el tejido social de la ciudad, la escuela no debe seguir siendo una isla dentro de la ciudad; y en otra dimensión, que la sociedad asuma su responsabilidad educativa, que los agentes sociales cumplan su función de educar a las futuras generaciones.

\section{LA PARTICIPACIÓN COMO PROCESO EDUCATIVO.}

\section{El ciudadano es aquel que ha participado en la conquista y construcción de la ciudad. \\ Jordi Borja}

Educar "es el acto político de ofrecer a la pulsión -deseo de saber- del ser humano un destino que no sea la inhibición, ni el síntoma, ni la angustia si no el despliegue de actividades creativas para aprender internándose para investigar lo desconocido, lo asombroso". ${ }^{30}$

Educar es el acto político que abre camino al conocimiento. Allí se asume al maestro como orientador integral o tutor, cuya función es mediar y facilitar procesos de aprendizaje, el diseño de actividades que permitan aprehender de la propia experiencia y que conduzca a la unidad entre escuchar, leer o escribir con la posibilidad de reflexión, autocrática y cambio.

Se trata de una actitud pedagógica permanente que rescate al ser humano en medio del drama, las crisis e incertidumbres de su momento histórico y relanza la confianza en sí misma, en las potencialidades
29 GÓMEZ-GRANELL, Carmen y VILA, Ignacio. La ciudad como proyecto educativo. Barcelona. Ediciones Octaedro, 2001. pág. 32

30 FRIGERIO, Graciela y DIKER, Gabriela. Educar ese acto político. Estante Editorial, Buenos Aires, 2005. Pág. 123

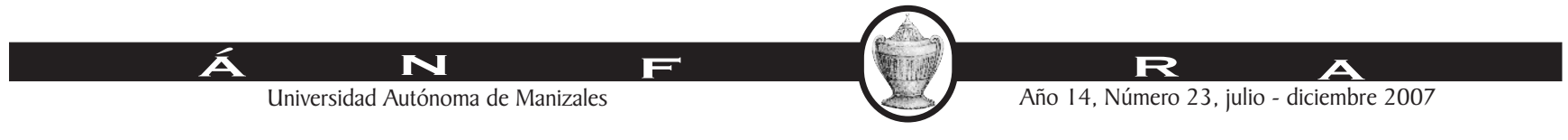


transformadoras de los múltiples saberes del pueblo para enfrentar la encrucijada de nuestra sociedad y los desafíos que se presentan.

¿Qué es la política, sino la puesta en cuestión de determinado problema y su superación? ¿Qué es politizar sino poner en discusión algo que se pretende inmutable, natural, transformar lo indiscutible en opinión, en juicio, en opción? ¿y para qué sirve conocer, sino para instrumentar y orientar esa transformación? ¿y qué es la educación entonces, desde una perspectiva política? También Gramsci había detectado ese problema, y esa unidad entre los dos procesos: "La relación pedagógica no puede ser limitada a las relaciones específicamente 'escolásticas', a través de las cuales las nuevas generaciones entran en contacto con las antiguas y absorben sus experiencias y sus valores históricamente necesarios 'madurando' y desarrollando una personalidad propia, histórica y culturalmente superior.

Esta relación existe en toda la sociedad en su conjunto y en todo individuo con relación a los otros individuos, bien como entre camadas intelectuales y no intelectuales, entre gobernantes y gobernados, entre elites y seguidores, entre dirigentes y dirigidos, entre vanguardia y cuerpos de ejército. Toda relación de 'hegemonía' es necesariamente una relación pedagógica, que se verifica no sólo en el interior de una nación, entre las diversas fuerzas que la componen, sino en todo campo nacional, internacional y mundial, entre conjuntos de civilizaciones nacionales y continentales." ${ }^{31}$

En definitiva, La existencia social del hombre, sólo puede conservarse a través del perfeccionamiento continuo de su conciencia social, en ello la educación juega un papel fundamental, de la eficacia con que se desarrolle, depende el logro de un sujeto reflexivo, comprometido con su entorno social y cultural. Al transmitir los rasgos fundamentales de la cultura, todo proyecto educativo, es también un acto político.

La educación de todas las sociedades, responde a un interés político, así como a los intereses de quienes detentan y ejercen el poder político. La política educacional, es por tanto derivación de la política.

Educar en y para la democracia implica crear las condiciones que hacen posible la vivencia y la práctica de dichos valores. Es por ello que la educación es un instrumento fundamental para la democracia, porque
31 GRAMSCI, Antonio, citado por GADOTTI, Moacir. Concepción dialéctica de la educación. Sao Paulo 1992, Pág. 7.

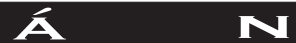

Universidad Autónoma de Manizales
F

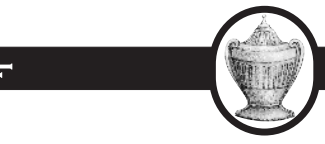

\section{$\mathbf{R}$}

Año I4, Número 23, julio - diciembre 2007 
no solo debemos transmitir conocimientos o contenidos (por ejemplo, aprender de memoria nuestros derechos constitucionales) sino, generar conductas sociales responsables que serán las que obrarán como el mejor guardián de los derechos inalienables de todos y cada uno de nosotros (siguiendo nuestro ejemplo: Cómo ejercer esos derechos y cómo respetar esos mismos derechos para los demás).

El concepto esta asociado a la acción -en palabras de Hannah Arendt-, por lo tanto un acto de emancipación que cuestione los valores y la estructura de una sociedad determinada y que actúe para corregirlos o transformarlos, es un movimiento que navega, irremediablemente, por aguas de lo político y de lo ético.

Pero la política se basa en el hecho de la pluralidad, trata del estar juntos y los unos con los otros de los diversos. (es decir, a partir de su diversidad). Los hombres se organizan políticamente según determinadas comunidades esenciales (...) a partir de un caos absoluto de diferencias. ${ }^{32}$ Este principio de la política es básico en su pensamiento, al punto de manifestarse decididamente contra aquellos que pretenden pensar los cuerpos políticos sobre el modelo de la familia y el parentesco. Dicha idea constituye una desviación muy común porque surge de la ausencia de refugio para la singularidad, propio de nuestra época: las familias se fundan como la única alternativa para la diversidad en un mundo que se ha vuelto inhóspito y extraño, de lo que se deriva el deseo de establecer parentescos. Pero tal idea conduce a la ruina de la política en la medida en que se pierde su cualidad fundamental, la pluralidad.

La participación está en el centro de la ciudadanía. Ella ha sido entendida como el conjunto de actividades voluntarias mediante las cuales los miembros de una sociedad participan en la selección de sus gobernantes $y$, directa o indirectamente, en la elaboración de la política gubernamental.

La participación es tomar parte activa. En palabras de Hannah Arendt, la ciudadanía activa - esto es, el compromiso cívico y la deliberación colectiva acerca de todos los temas que afectan a la comunidad política sólo tiene sentido y posibilidad de ser en el espacio en que se construye lo público. El núcleo de la participación es el poder, y por ello supone la
32 ARENDT, Hannah. ¿Qué es la política?. Barcelona. 1987. Pág. 45.
A N

Universidad Autónoma de Manizales 
capacidad humana de actuar en concierto; el poder, en este sentido, no es nunca propiedad de un individuo, sino que pertenece al grupo y existe sólo mientras éste exista.

La esfera pública alude al espacio donde los ciudadanos interactúan mediante los recursos del discurso y la persuasión, descubren sus identidades y deciden, en deliberación colectiva, acerca de los temas de interés común.

Al hablar de una ciudadanía que interroga las relaciones de dominación nos encontramos con la tesis central de Arendt, ${ }^{33}$ quien la plantea como el espacio de construcción de lo público y cuya concepción de la política está basada en la idea de la ciudadanía activa, esto es, en el valor e importancia del compromiso cívico y de la deliberación colectiva acerca de todos los temas que afectan la comunidad política. Es decir, si la dimensión pasiva de la ciudadanía está dada por el acceso de derechos civiles, políticos o sociales-, la dimensión activa está dada por las responsabilidades que los sujetos tienen con la comunidad política a la que pertenecen.

Para Arendt, los espacios públicos cobran existencia siempre que los ciudadanos se agrupan por el discurso y la acción, ${ }^{34}$ confiriéndole poder a esa acción. Esta autora valora el espacio público como aquel donde los ciudadanos interactúan mediante los recursos del discurso y la persuasión, descubren sus identidades y deciden mediante la deliberación colectiva acerca de los temas de interés común.

En este sentido, la esfera pública es aquella dentro de la cual la actividad de la ciudadanía puede florecer. La práctica de la ciudadanía es valorada porque capacita a cada ciudadano a ejercer sus poderes de acción, a desarrollar sus capacidades de juicio y a lograr, por acción concertada, algunas medidas de eficacia política.

La reactivación de la ciudadanía en el mundo moderno, para Arendt, depende tanto de la recuperación de un mundo común y compartido como de la creación de numerosos espacios públicos en donde los individuos pueden demostrar sus identidades y establecer relaciones de reciprocidad y solidaridad.
33 Cfr. ARENDT, Hannah. La condición humana, Paidós, Barcelona, 1993

34 Cfr. ARENDT, Hannah. Op. Cit. Pág. 45
A N

Universidad Autónoma de Manizales 
El espacio público es valorado también como "fuente de las funciones de crítica y control que la sociedad ejerce sobre la cosa pública -y como instancia- que hace posible la conexión del principio de igualdad política con el de la participación de los ciudadanos en lo que es de interés común". ${ }^{35}$ Es decir, un aspecto fundamental de la vigencia actual de la democracia es el desarrollo de espacios públicos, diferentes del Estado, lo que da cuenta de la vitalidad y autonomía de la sociedad civil. Por ello la ciudadanía activa tiene relación con ser sujeto de derechos y sujeto de la construcción pública común, es decir, actor/a en la creación de espacios, intereses, imágenes y discursos públicos, con sentido de identidad, pertenencia y membresía a una determinada comunidad política, entre cuyos miembros hay relaciones de interdependencia, responsabilidad, solidaridad y lealtad.

El concepto de Arendt resulta propicio, asimismo, para recoger las nociones de diversidad y pluralismo, y de ampliación del espacio público, que hoy parecen indispensables para una construcción democrática sustentada en la fortaleza y diversidad de la sociedad civil.

La ciudadanía activa se basa en el supuesto de una práctica crítica capaz de exigir el cumplimiento de normas jurídicas preestablecidas, de nombrar las carencias de aquellas personas que no han sido definidas como sujetos de derechos y de formular nuevos derechos que surgen con la complejidad creciente de las problemáticas de la vida contemporánea. Desde esta perspectiva, la historia de los movimientos sociales, puede interpretarse como una tendencia a incrementar el ejercicio futuro de la ciudadanía. ${ }^{36}$

En otros términos, una cultura política y democrática debiera abrir espacio a una ciudadanía deliberativa, como criterio clave para discernir el significado de la participación. La ciudadanía deliberativa va más allá de que la gente se beneficie, más o menos equitativamente, de las políticas públicas o de que las actividades privadas se regulen para evitar los privilegios de unos sobre otros.

La ciudadanía deliberativa supone tanto el interés de la gente como sus posibilidades reales de intervenir e influir en la toma de las decisiones que afectan al conjunto de la sociedad. La ciudadanía deliberativa implica que la gente ejerza su capacidad reflexiva y que exprese sus ideales e intereses, organizándolos, articulándolos y negociándolos en
35 BRESSER, Luís Carlos. Entre el Estado y el mercado: lo público no estatal, en lo público no estatal en la reforma del Estado. CLAD-Paidós, Argentina, 1998, pág. 25

36 Cfr. JELIN, Elizabeth. ¿C ó mo constru i r democracia? Una visión desde abajo. Caracas. 1995, pág. 56

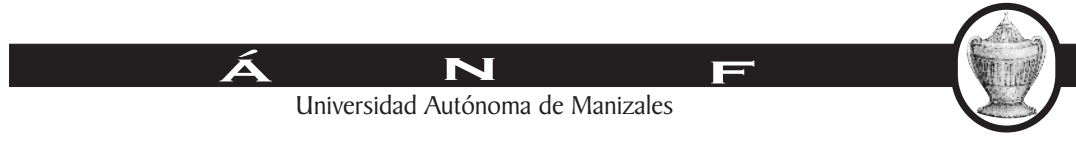


el ámbito social. De allí la discusión respecto de que sólo ciertas formas de participación constituyen expresión ciudadana.

Participar significa que la gente sea capaz de estar activamente presente en los procesos de toma de decisiones que atañen al colectivo, ahora bien, la participación ciudadana en la gestión pública, la entendemos en el proceso de intervención de la Sociedad Civil individuos y grupos organizados - en las decisiones y acciones que los afectan a ellos y a su entorno; y, por ciudadanía, la reivindicación de un sujeto de derechos y responsabilidades frente a un determinado poder, la participación ciudadana corresponde a la movilización de estos intereses de la Sociedad Civil en actividades públicas.

La participación ciudadana reconoce intereses públicos y políticos ante los que apela, pero lo que está pidiendo es precisamente el reconocimiento del carácter público que tiene su interés privado. Sin embargo, ese interés privado no se transforma en público, sino que solamente se puede hacer pública la consideración de ese interés.

Políticamente, la participación ciudadana apunta al tema del régimen político en cuanto procedimiento de constitución de la voluntad política. En concreto, ha estado referida a la sustitución o complementación de la democracia representativa. Es puesta de relieve como un valor central no sólo en términos del impacto de las apuestas de desarrollo, sino también como un componente esencial a un modelo más equitativo, justo y democrático.

La participación ciudadana pareciera encontrar su terreno privilegiado en la gestión pública o en la administración como una forma de mejorar su funcionamiento $y$, por ende, se asocia estrechamente a la modernización del Estado. Si por gestión pública entendemos la manera de organizar el uso de los recursos para el cumplimiento de los objetivos y tareas del Estado, la participación ciudadana en la gestión pública se refiere al rol del ciudadano en cuanto partícipe y en cuanto usuario de las decisiones y gestiones asociadas a la implementación de acciones públicas.

En síntesis, el tema de la participación ciudadana se ubica en el terreno de la existencia de un poder público que pretende ser expresivo del 
interés general de la Sociedad Civil, y de una administración que realiza la orientación establecida por el poder público, hoy el Estado contemporáneo necesita de la participación en sus Políticas Públicas, con el fin de cumplir con sus propósitos de perfeccionar la gestión pública, fortalecer la democracia y robustecer el capital social y el fortalecimiento de la Sociedad Civil.

Entre tanto, la expansión y redefinición de la ciudadanía ya no se agota en los derechos cívicos, económicos y sociales, sino que se proyecta a muy diversos campos de la vida social. La lucha por estos nuevos derechos extiende el concepto de ciudadanía - reivindicación de un sujeto de derecho frente a un determinado poder - e implica una nueva definición de la ciudad. Por tanto, uno de los componentes básicos del régimen democrático -la ciudadanía- cambia de significado y exige nuevas instituciones que se hagan cargo de él.

La participación ciudadana contribuye a la redefinición de lo público, quitándole el uso exclusivo de lo público a lo estatal y propiciando conquistas al margen del mercado y el Estado.

Los espacios abiertos a la participación ciudadana tendrán potencialidad para un buen gobierno si se dan a lo menos tres condiciones: que gocen de una efectiva autonomía frente al Estado y a los intereses corporativos de los grupos económicos; que no puedan ser sustituidos por la política partidista; y que se construyan desde abajo, desde experiencias con organizaciones de base y no al amparo de un paternalismo centralista.

Por tanto, el crecimiento, diversificación y fortalecimiento de los actores sociales implica un incremento de los niveles de participación. Ésta no debería limitarse a una dimensión simbólica, sino estar dirigida también a la solución efectiva de los problemas, lo que plantea la cuestión de la descentralización del poder del Estado.

Finalmente, digamos con Edgar Morin, la democracia necesita tanto conflictos de ideas como de opiniones que le den vitalidad y productividad. Pero la vitalidad y la productividad de los conflictos sólo se puede expandir en la obediencia a la norma democrática que regula los antagonismos reemplazando las batallas físicas por las batallas de ideas, y determina por la vía de los debates y las elecciones un vencedor 
provisional de las ideas en conflicto, el cual, a cambio, tiene la responsabilidad de dar cuenta de la realización de sus ideas.

Exigiendo a la vez, consenso, diversidad y conflicto, la democracia es un sistema complejo de organización y de civilización políticas que alimenta y se alimenta de la autonomía de espíritu de los individuos, de su libertad de opinión y de expresión, de su civismo que alimenta y se alimenta del ideal, "Libertad, Igualdad, Fraternidad", el cual comporta un conflicto creador entre estos tres términos inseparables.

La democracia constituye por consiguiente un sistema político complejo en cuanto que vive de pluralidades, competencias y antagonismos permaneciendo como una comunidad.

Así, la democracia constituye la unión de la unión y de la desunión; tolera y se alimenta endémicamente, a veces explosivamente, de conflictos que le dan vitalidad. Ella vive de pluralidad hasta en la cima del Estado (división de los poderes ejecutivo, legislativo y judicial) y debe conservar esta pluralidad para conservarse ella misma.

El desarrollo de las complejidades políticas, económicas y sociales nutre los desarrollos de la individualidad y ésta se afirma en sus derechos humano y del ciudadano-; adquiere libertades existenciales (elección autónoma del cónyuge, de la residencia, de los placeres. ${ }^{37}$

Estanislao Zuleta nos dice: "Es muy fácil elogiar la democracia, pero es muy difícil aceptarla en el fondo porque la democracia es aceptación de la angustia de tener que decidir por sí mismo". ${ }^{38}$

La educación necesita alimentar este anhelo humano con un sentido de responsabilidad y cuidado, no como mero formalismo y formulismo, requiere de una práctica concreta a la cual se sujete y que implique necesariamente al maestro de modo fundamental, como se realiza en las comunidades de diálogo.

La democracia exige un sistema pensante porque su práctica es a base de disertaciones, diálogos, consensos y buenos juicios; el espacio donde debe primar no el mejor argumento, sino el más razonable. En este sentido la filosofía como disciplina reflexiva, como arte de diálogo epistémico, de las buenas razones, de la lógica humanizada, resulta
37 MORIN, Edgar. Enseñar democracia. Fragmento del Capítulo VII "La ética del género humano", del libro publicado por la UNESCO, "Los siete saberes necesarios a la educación del futuro". Pág. 45

38 ZULETA, Estanislao. Educación y Democracia, un campo de combate. Corporación Tercer Milenio. Bogotá 1995. pág. 27

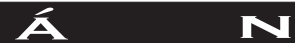

Universidad Autónoma de Manizales
$F$

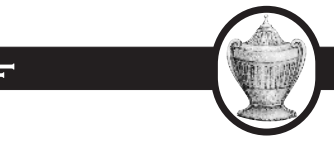


necesariamente ser su aliado indispensable. Si hemos pues de pretender por una educación pensante y que desee reconocer los valores humanos fundamentales, necesita en consecuencia de una educación con filosofía a todo nivel. Sin embargo, debemos reconocer que existe un miedo latente y concreto al abordar tanto una educación con filosofía como democrática, pues por un lado existe el miedo ya mencionado a instancias de ese anhelo de dogma que guíe, nos "controle" y nos calme con una relativa seguridad, pero por el otro, nos exige ser modestos porque nos lleva a reconocer la pluralidad de sentires y creencias, visiones, etc.

Esto implica por su puesto, refutar o confirmar, defender o cambiar los criterios al ser enriquecidos por otros, asumir la imperativa necesidad de escuchar. Aquí respeto significa tomar al otro en serio sin entrar en ofensas y burlas, porque no se trata simplemente de medir el grado de verdad que el otro posee. La discusión o el diálogo filosófico se colocan en la relación con el punto de vista del otro, sin saber a ciencia cierta su resultado, que siempre ha de ser ganancioso. Zuleta nos dice: "En un debate seriamente llevado no hay perdedores: quien pierde gana, sostenía un error y salió de él; quien gana no pierde nada, sostenía una teoría que resultó corroborada". ${ }^{39}$

\section{PALABRAS FINALES.}

\section{La ciudad es una obra de arte escrita con las pinceladas de los hombres y mujeres que la recorren. Jahir Rodríguez R.}

\section{La escuela de la Ciudad Educadora.}

Sueño con una escuela vestida con los colores del arco iris, con niños y jóvenes que sonríen y persiguen por sus rincones el encanto y la magia del conocimiento y el arte, con maestros lúdicos y democráticos que son capaces de aventurar el entusiasmo de sus discípulos por los caminos más fantásticos e intrincados, de untarse de la curiosidad de los niños y de crecer como adultos conducidos de la mano de ellos.

Sueño con una escuela sin obligaciones, ni castigos, sin tareas, sin evaluaciones, sin llanto, sin ninguna preocupación distinta a la de construir diariamente el conocimiento con la materia prima de las
39 Ibid. Pág. 38

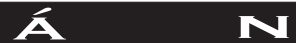

Universidad Autónoma de Manizales 
necesidades inmediatas, no creo en las escuelas que forman para el futuro, sacrificando las urgencias del presente, que enseñan con rigor "científico", toneladas de conocimientos que carecen de sentido para los niños y jóvenes, para sus expectativas de vida, para sus ilusiones y urgencias.

Sueño con una escuela en la que se aprende a aprender, a investigar, a decidir, a actuar, a participar, a comunicarse; todo en una atmósfera de libertad y afecto, de respeto por las diferencias, de enternecimiento permanente, de lúdica fantasía.

Desconfía de aquellos que te enseñan listas de nombres fórmulas y fechas y que siempre repiten modelos de cultura que son la triste herencia que aborreces.

No aprendas sólo cosas piensa en ellas y construye a tu antojo situaciones e imágenes que rompan la barrera que aseguran que existe entre la realidad y la utopía.

Después sal a la calle y observa: es la mejor escuela de tu vida.

La escuela en la que nos hemos formado hasta ahora ha sufrido de una enfermedad crónica: LA CORDURA. Atada a normas y programas prefijados, convirtió a niños y maestros en víctima de la tiranía de los diseñadores de currículos, de los fabricantes de libros, de los inventores de reformas educativas, de los indicadores de evaluación.

Para esta enfermedad no existe otro remedio que la locura, como un espacio para potenciar el imaginario, arriesgar caminos, abordar el delirio de la incertidumbre y la búsqueda permanente de cosas nuevas, distintas y gratificantes. Un espacio para crecer sin ataduras al ritmo de nuestras propias urgencias y necesidades, sin otro interés que nosotros mismos y nuestra vida, construida desde nuestras propias formulaciones éticas, morales, científicas, culturales y artísticas.

Ciudad Educadora. La Ciudad Educadora, propósito fundamental en la construcción de ciudadanía,debe estar pensada en lo que Eduardo Galeano ha denominado educando con el ejemplo: "La escuela del mundo al revés es la más democrática de las instituciones educativas. 
No exige examen de admisión, no cobra matricula y gratuitamente dicta sus cursos, a todos y en todas partes, así en la tierra como en el cielo: por algo es hija del sistema que ha conquistado, por primera vez en toda la historia de la humanidad, el poder universal. En la escuela del mundo al revés, el plomo aprende a flotar y el corcho a hundirse. Las víboras aprenden a volar y las nubes a arrastrarse por los caminos"40

Ciudad Educadora, defiende un proyecto de educación como lo ha venido sosteniendo Gabriel García Márquez: "Una educación desde la cuna hasta la tumba, inconforme y reflexiva, que nos inspire un nuevo modo de pensar y nos incite a descubrir quiénes somos en una sociedad que se quiera más a sí misma. Que aproveche al máximo nuestra creatividad inagotable y conciba una ética - y tal vez una estética - para nuestro afán desaforado y legitimo de superación personal. Que integren las ciencias y las artes a la canasta familiar, de acuerdo con los designios de un gran poeta de nuestro tiempo que pidió no seguir amándolas por separado como a dos hermanas enemigas. Que canalice hacía la vida la inmensa energía creadora que durante siglos hemos despilfarrado en la depredación y la violencia, y nos abra al fin la segunda oportunidad sobre la tierra que no tuvo la estirpe desgraciada del Coronel Aureliano Buendía...". ${ }^{41}$

En definitiva, Ciudad Educadora, es una ciudad forjada por los sueños de todos y hecha a la medida de nuestras fantasías y esperanzas. Es un proyecto político: proactivo, propositivo y prospectivo que se construye día a día, con la alegría de la vida y sin permiso.

\section{Por los senderos de la Ciudad Educadora.}

Se hace camino al andar. Machado

- Hoy, levántate como sin costumbres, deja despeinado el semblante de tu sueño, enmochila el botín de tu infancia, ponte las sudaderas del juego y calza las pantuflas apropiadas para tus ilusos caprichos. Sobre todo, no te afeites la sonrisa y vete a disfrutar con otros del carnaval increíble de los fabulosos oficios del ocio.

- En este día, la alegría labora en jornada continua, la fantasía trabaja horas extras, la imaginación se va de vacaciones. No saques paraguas porque es inútil conjurar la lluvia. Es un día como para aceitar los
40 GALEANO, Eduardo. Patas Arriba. La escuela del mundo al revés. TM Editores. Bogotá. 1998. pág. 5.

41 GARCIA MARQUEZ, Gabriel. Por un país al alcance de los niños. Proclama. En: Antología de la tolerancia. Papiro. Pereira. 1995, pág. 32.

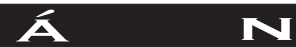

Universidad Autónoma de Manizales
$F$

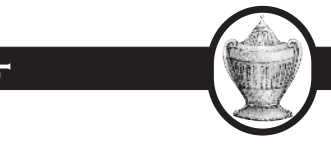


engranajes secretos de la risa, afilar ganzúas para desactivar los resortes de la rabia y desconectar los oscuros mecanismos del miedo. Como para ensamblar las ceremonias privadas del ensueño y violar los paredones prohibidos del fastidio.

- Ve a darle cuerda de nuevo a tus mágicos juegos. Habrá campos de adiestramiento para la alegría, centros de atención inmediata a tu ilusión, salas de espera a tu inquietud, salida de emergencias a tus angustias. Hay vías de acceso al desespero, tránsito libre a la euforia, vía cerrada al desencanto. Habrá una antena parabólica rastreando el rumbo melódico del aire, la policromía acústica del viento, el ritmo infatigable de las quejas de la luna.

- Habrá mapas de fuga para eludir el descontento, planes de evasión para escapar a los territorios baldíos del sueño, por lo tanto, se decreta y sanciona:

Primero. Queda decretado que ahora vale la vida, que ahora vale la verdad y que de manos dadas, trabajaremos todos por la vida verdadera.

Segundo. Queda decretado que todos los días de la semana, incluso los martes más grises, tienen derecho a convertirse en mañanas de domingo.

Tercero. Queda decretado que, a partir de este instante, habrá girasoles en todas las ventanas, que los girasoles tendrán derecho a abrirse dentro de la sombra y que las ventanas deben permanecer el día entero abiertas para el verde donde crece la esperanza.

Cuarto. Queda decretado que el hombre no precisará más dudar del hombre. Que el hombre confiará en el hombre como la palmera confía en el viento, como el viento confía en el aire, como el aire confía en el campo azul del cielo. El hombre confiará en el hombre como un niño confía en otro niño.

Quinto. Queda decretado que los hombres están libres del yugo de la mentira. Nunca más será preciso usar la coraza del silencio ni la armadura de las palabras. El hombre se sentará a la mesa, con la mirada limpia porque la verdad pasará a ser servida antes del postre. 
Sexto. Queda establecida, durante diez siglos, la práctica soñada por el profeta Isaías y el lobo y el cordero pastarán juntos y la comida de ambos tendrá el mismo gusto a la aurora.

Por último y primero. Queda prohibido el uso de la palabra libertad la cual será suprimida de los diccionarios y del pantano engañoso de las bocas. A partir de este instante, la libertad será algo vivo y transparente como un fuego o como la semilla del trigo y su morada será siempre el corazón del hombre.

\section{BIBLIOGRAFÍA.}

ARENDT, Hannah. La Condición Humana. Paidós. Barcelona. 1993.

1976.

Los orígenes del totalitarismo, Madrid, Taurus, . ¿Qué es la política? Barcelona. 1987.

LARRAURI, Maite, La Libertad, según Hannah Arendt. Valencia, Tándem Ediciones, 2001

BRESSER, Luís Carlos. Entre el Estado y el mercado: lo público no estatal, en lo público no estatal en la reforma del Estado. CLAD-Paidós, Argentina, 1998.

BOBBIO, Norberto. Diccionario de Política. Editora Universidad de Brasilia, Brasilia, 1986.

COLOM CAÑELLAS, Antonio J. La Pedagogía Urbana, Marco Conceptual de la Ciudad Educadora. En: La Ciudad Educadora. Barcelona. 1990.

CASTORIADIS, Cornelius. La democracia como procedimiento y como régimen. Madrid. 1996

Declaración del Primer Encuentro Internacional de Ciudades Educadoras. Barcelona. 1990

DEBRAY, Régis. Transmitir. Ediciones Manantial, Argentina, 1997.

DIETZ, Mary. El contexto es lo que cuenta. Buenos Aires.1987. 
FAURE, Edgar. Aprender a ser. UNESCO. Madrid. 1973.

FREIRE, Paulo. Política y educación. Santiago de Chile. 1990.

FRIGERIO, Graciela y DIKER, Gabriela. Educar ese acto político. Estante Editorial, Buenos Aires, 2005.

GIROUX, Henry. Los profesores como intelectuales. Paidós. Barcelona, 1990.

GENNARI, Mario. Semántica de la ciudad y educación. Pedagogía de la ciudad. Herder. Barcelona. 1995.

GANTIVA SILVA, Jorge. Un ensayo sobre Gramsci. Ed. Magisterio. Bogotá. 1998.

GALEANO, Eduardo. Patas Arriba. La escuela del mundo al revés. TM Editores. Bogotá. 1998.

GARCIA MARQUEZ, Gabriel. Por un país al alcance de los niños. Proclama. Papiro. Pereira. 2000

HABERMAS, Jürgen. El nexo interno entre estado de derechos y democracia. Bogotá. 1997.

- Teoría de la acción comunicativa, Buenos Aires,

1989.

HOYOS ZULUAGA, Gustavo Alberto. Conversaciones sobre el proceso de Planeación y Presupuesto Participativo. Entrevista. Manizales, marzo de 2005.

JELIN, Elizabeth. ¿Cómo construir democracia? Una visión desde abajo. Caracas. 1995

MARION YOUNG, Iris. Inclusión y democracia. San José de Costa Rica. 2000.

MARINA TORRES, José Antonio. La conspiración educativa. Navarra. 2005

MEDINA GALLEGO, Carlos, Caja de Herramientas para transformar la escuela. Quito Editores. Bogotá, 1996. 
MOLAS BATLLORI, Isidre. La ciudad y la ciudadanía democrática. Una perspectiva política. En: La Ciudad Educadora. Barcelona. 1990.

MORIN, Edgar. Enseñar democracia. Madrid. 2005.

TAYLOR, Charles. Argumentos filosóficos: ensayos sobre el conocimiento, el lenguaje y la modernidad. Editorial Paidós, Barcelona. 1994.

TORO, Bernardo. Los siete aprendizajes básicos para la convivencia social. Bogotá. 1994.

TOURAINE, Alían. Carta a los Socialistas. Lisboa, 1996.

TIZIO, Hebe. La categoría de inadaptación social. En: PETRUS, Antonio. Pedagogía Social. Barcelona, Ariel, 1997

RAMÍREZ CARDONA, Néstor Eugenio. Entrevista. Manizales, 2005.

RODRIGUEZ RODRIGUEZ, Jahir. EL PRESUPUESTO PARTICIPATIVO EN MANIZALES: Un aprendizaje en la construcción de la ciudadanía. Revista ANFORA. Universidad Autónoma de Manizales. No. 19. 2006.

SAVATER, Fernando, La tarea del héroe. Editorial Destino, México, 1994.

ZULETA, Estanislao. Educación y Democracia, un campo de combate. Corporación Tercer Milenio. Bogotá 1995. 


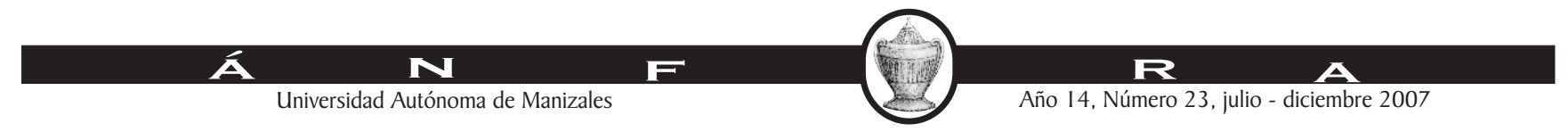

